\title{
Robustness evaluation of the chromatographic method for the quantitation of lumefantrine using Youden's test
}

\author{
Isabela da Costa César*, Gerson Antônio Pianetti \\ Department of Pharmaceutical Products, Faculty of Pharmacy, Federal University of Minas Gerais
}

\begin{abstract}
Youden's test is a reliable method to evaluate the robustness of analytical methods, by means of an experiment design which involves seven analytical parameters combined in eight tests. In the present study, we assessed the robustness of a chromatographic method to quantify lumefantrine in raw material samples, using Youden's test. Hence, it was possible to determine the effect of each analytical parameter in the final analysis results. Youden's test showed to be a simple and feasible procedure to evaluate the robustness of chromatographic methods.
\end{abstract}

Uniterms: Lumefantrine/determination. Youden's test. High Performance Liquid Chromatography/ quantitative analysis.

\begin{abstract}
O teste de Youden constitui um método confiável para avaliação da robustez de métodos analíticos, por meio de um delineamento que envolve sete parâmetros analíticos combinados em oito experimentos. No presente estudo, a robustez de um método cromatográfico para quantificação de lumefantrina em matéria-prima farmacêutica foi avaliada utilizando-se o teste de Youden. Assim, foi possível determinar o efeito de cada parâmetro analítico nos resultados finais das análises. $\mathrm{O}$ teste de Youden se mostrou um procedimento simples e confiável para a avaliação da robustez de métodos cromatográficos.
\end{abstract}

Unitermos: Lumefantrina/determinação. Teste de Youden. Cromatografia Líquida de Alta Eficiência/ análise quantitativa.

\section{INTRODUCTION}

In pharmaceutical analysis, often an intensive method validation is required, in order to meet the strict regulations set by the regulatory authorities. In this context, nowadays, robustness testing is gaining interest and becoming increasingly more important. In the past, these tests were often not performed due to their complexity, to the many possible experimental set-ups (usually by experimental designs) and analysis methods, and also due to the lack of guidelines (Dejaegher, Heyden, 2007).

The robustness of an analytical method is the measure of its capacity to remain unaffected by small, but deliberate variations in method parameters, and provides an indication of its reliability during normal usage. The robustness of a chromatographic method, for example,

\footnotetext{
*Correspondence: I. C. César. Departamento de Produtos Farmacêuticos, Faculdade de Farmácia, Universidade Federal de Minas Gerais. Av. Pres. Antônio Carlos 6627 - 31270-901 - Belo Horizonte - MG, Brasil. E-mail: isaccesar@bol.com.br
}

may be evaluated by variations in parameters such as mobile phase composition, $\mathrm{pH}$ and ionic strength, temperature and different lots or suppliers of columns $(\mathrm{ICH}$, 1996; Brasil, 2003; The United States Pharmacopoeia, 2007). The evaluation of robustness should be considered during the method development phase. In fact, the process of validating a method cannot be separated from the actual development of the method conditions, since it is not possible to know whether the method conditions are acceptable until validation studies are performed. The development and validation of a new analytical method may therefore be an interative process (Green, 1996).

The evaluation of the robustness of chromatographic methods often is complex and laborious, taking into account the large number of analytical parameters that should be considered to carry out the test. Some authors select specific analytical parameters to be evaluated, introducing small variations in the nominal conditions and the statistical interpretation is performed by means of Student's $t$-test or ANOVA test (Dejaegher, Heyden, 2007). 
Other wider alternative to determine the robustness of analytical methods is the Youden's test. This test allows not only evaluating the method robustness but also pointing out the influence of each analytical parameter in the final results. The basic idea of Youden's test is not to study one alteration at time but to introduce several changes at once, in such a manner that the effects of individual changes can be ascertained (Youden, Steiner, 1975; Inmetro, 2003).

In the Youden's test, seven analytical parameters are selected to be evaluated and eight runs are carried out in a factorial combination to determine the influence of each parameter in the final result. The runs are performed with the analytical conditions at their nominal value and with a slight variation (Youden e Steiner, 1975; INMETRO, 2003). If measurements are susceptible to variations in analytical conditions, these conditions should be suitably controlled or a precautionary statement should be included in the procedure, aiming to control and to monitor these variations (ICH, 1996; Brasil, 2003).

The aim of the work was to evaluate the robustness of the chromatographic method for the quantitation of lumefantrine, using Youden's test, and determine the analytical parameters that present higher influence in the final results of the analysis.

Lumefantrine is an antimalarial widely used in malaria endemic areas (Figure 1), generally associated with artemether, in fixed dose combination tablets.

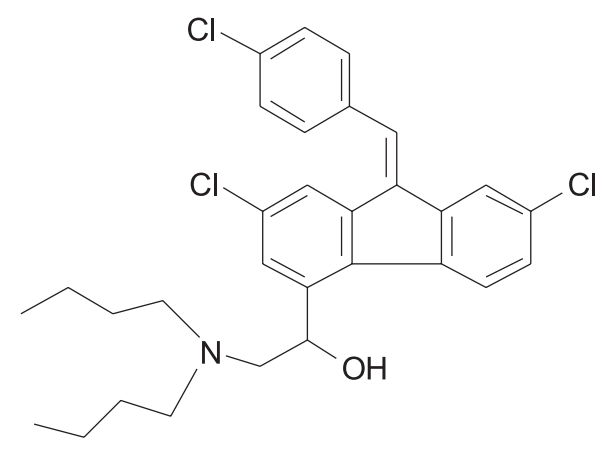

FIGURE 1 - Lumefantrine chemical structure.

Many studies have demonstrated that this association is highly effective in the treatment of resistant $P$. falciparum malaria, resulting in high cure rates and prevention against reinfection (Bakshi et al., 2000; Martensson et al., 2005; Sutherland et al., 2005). Nowadays, the lumefantrine-artemether association is the first line therapy recommended by Brazilian Health Ministry to the falciparum malaria treatment (Brasil, 2006).

Some studies available in the literature describe the quantitation of lumefantrine by HPLC with UV detection, in plasma or blood (Mansor et al., 1996; Annerberg et al., 2005; Lindegardh et al., 2005) and in pharmaceutical products (César et al., 2008). At the present work, the robustness of a chromatographic method for the quantitation of lumefantrine in raw materials was evaluated by means of Youden's test.

\section{MATERIALS AND METHODS}

\section{Reagents and materials}

Lumefantrine chemical reference substance and raw material were purchased from Dafra Pharma (Turnhout, Belgium). Methanol, trifluoroacetic acid and dichloromethane (HPLC grade) were purchased from Tedia (Fairfield, $\mathrm{OH}$, USA). Water was purified using a Millipore system (Bedford, MA, USA).

\section{Chromatographic conditions}

The HPLC analyses were carried out on Agilent 1200 and HP 1100 systems (Palo Alto, CA, USA), both composed of quaternary pump, autosampler, diode array detector (DAD) and HP ChemStation software. The columns used were Symmetry $C_{18}(250$ x 4.6 mm i.d.; $5 \mu \mathrm{m}$ particle size $)$ from Waters, and $\mathrm{Ace}_{18}(250 \times 4.6 \mathrm{~mm}$ i.d.; $5 \mu \mathrm{m}$ particle size) from ACT, both maintained at $30{ }^{\circ} \mathrm{C}$. The mobile phase consisted of methanol and trifluoroacetic acid $0.05 \%(\mathrm{v} / \mathrm{v})(80: 20), \mathrm{pH} 2.8$, at a flow rate of 1 $\mathrm{ml} / \mathrm{min}$. The detection was performed at $335 \mathrm{~nm}$ and the injection volume was $20 \mu 1$.

\section{Preparation of lumefantrine standard and sample solutions}

Standard solution: approximately $15 \mathrm{mg}$ of lumefantrine reference standard were accurately weighed and transferred to a $50 \mathrm{ml}$ volumetric flask. An aliquot of $1 \mathrm{ml}$ of dichloromethane was added to ensure the complete solubilization and the volume was completed with methanol. An aliquot of $4 \mathrm{ml}$ of the obtained solution was transferred to a $50 \mathrm{ml}$ volumetric flask and the volume was adjusted with mobile phase, so that the final concentration was 24 $\mu \mathrm{g} / \mathrm{ml}$.

Sample solution: approximately $30 \mathrm{mg}$ of lumefantrine raw material were accurately weighed and transferred to a $100 \mathrm{ml}$ volumetric flask. An aliquot of $2 \mathrm{ml}$ of dichloromethane was added to ensure the complete solubilization and the volume was completed with methanol. An aliquot of $4 \mathrm{ml}$ of the obtained solution was transferred to a $50 \mathrm{ml}$ 
volumetric flask and the volume was adjusted with mobile phase.

\section{Robustness evaluation by means of Youden's test}

The robustness evaluation of the chromatographic method for the lumefantrine quantitation was performed using the method proposed by Youden e Steiner (1975). Seven analytical parameters were selected and small variations were induced in the nominal values of the method. Then, eight runs were performed aiming to determine the influence of each parameter in the final result. The seven analytical parameters employed, as well as the introduced variations are demonstrated at Table I. The analytical conditions at the nominal values are represented by capital letters and the conditions with the small variation are represented by lowercase letters.

The seven parameters and its respective variations were combined in eight assays or chromatographic runs, performed in a random order. Table II demonstrates the factorial combination of the parameters for the Youden's test. The analyses results are shown by letters from $s$ to $z$. Hence, when combination 1 was assayed, the obtained result was $s$. When combination 2 was assayed, the obtained result was $t$, and so successively.

In each combination, three injections of each sample and standard solutions were carried out, at the work concentration $(24 \mu \mathrm{g} / \mathrm{ml})$. After the change of chromatographic column or mobile phase composition, $30 \mathrm{~min}$ were awaited for system stabilization. The evaluated results in each combination were peak area, retention time $(\mathrm{Rt})$, tailing factor $(\mathrm{T})$, theoretical plates number $(\mathrm{N})$ and lumefantrine content.

To determine the influence of variations of each parameter in the final result, the mean of the four values corresponding to the capital letters (nominal conditions) was compared to the mean of the four values corresponding to the lowercase letters (altered conditions). For example, to evaluate the effect of the column temperature in the final result of the analyses, the following equation was employed:

Effect $\mathrm{C} / \mathrm{c}=\frac{s+u+w+y}{4}-\frac{t+v+x+z}{4} \quad$ Eq. (1)

Thus, the influence of the seven analytical parameters regarding the peak area, retention time (Rt), tailing factor

TABLE I - Analytical parameters and variations for the robustness evaluation of the chromatographic method for lumefantrine quantitation

\begin{tabular}{|c|c|c|c|c|c|c|c|}
\hline \multirow[b]{2}{*}{$\mathrm{A} / \mathrm{a}$} & \multirow{2}{*}{$\begin{array}{l}\text { Parameter } \\
\text { Methanol concentration in mobile phase }\end{array}$} & \multicolumn{3}{|c|}{ Nominal condition } & \multicolumn{3}{|c|}{ Variation } \\
\hline & & $80 \%$ & - & $\mathrm{A}$ & $77 \%$ & - & $\mathrm{a}$ \\
\hline $\mathrm{B} / \mathrm{b}$ & Mobile phase $\mathrm{pH}$ & 2.8 & - & B & 3.1 & - & $\mathrm{b}$ \\
\hline $\mathrm{C} / \mathrm{c}$ & Column temperature & $30^{\circ} \mathrm{C}$ & - & $\mathrm{C}$ & $35^{\circ} \mathrm{C}$ & - & $\mathrm{c}$ \\
\hline $\mathrm{D} / \mathrm{d}$ & Mobile phase flow rate & 1.0 & - & $\mathrm{D}$ & 1.2 & - & d \\
\hline $\mathrm{E} / \mathrm{e}$ & Column supplier & Symmetry & - & $\mathrm{E}$ & Ace & - & e \\
\hline $\mathrm{F} / \mathrm{f}$ & Methanol supplier & Tedia & - & $\mathrm{F}$ & J.T. Baker & - & $\mathrm{f}$ \\
\hline $\mathrm{G} / \mathrm{g}$ & Chromatograph model & Agilent 1200 & - & G & HP 1100 & - & $\mathrm{g}$ \\
\hline
\end{tabular}

TABLE II - Factorial combination of the analytical parameters for robustness evaluation by Youden's test

\begin{tabular}{lcccccccc}
\hline Analytical parameter & \multicolumn{1}{c}{ Factorial combination } \\
\cline { 2 - 9 } & $\mathbf{1}$ & $\mathbf{2}$ & $\mathbf{3}$ & $\mathbf{4}$ & $\mathbf{5}$ & $\mathbf{6}$ & $\mathbf{7}$ & $\mathbf{8}$ \\
\hline Methanol concentration & $\mathrm{A}$ & $\mathrm{A}$ & $\mathrm{A}$ & $\mathrm{A}$ & $\mathrm{a}$ & $\mathrm{a}$ & $\mathrm{a}$ & $\mathrm{a}$ \\
Mobile phase pH & $\mathrm{B}$ & $\mathrm{B}$ & $\mathrm{b}$ & $\mathrm{b}$ & $\mathrm{B}$ & $\mathrm{B}$ & $\mathrm{b}$ & $\mathrm{b}$ \\
Column temperature & $\mathrm{C}$ & $\mathrm{c}$ & $\mathrm{C}$ & $\mathrm{c}$ & $\mathrm{C}$ & $\mathrm{c}$ & $\mathrm{C}$ & $\mathrm{c}$ \\
Mobile phase flow rate & $\mathrm{D}$ & $\mathrm{D}$ & $\mathrm{d}$ & $\mathrm{d}$ & $\mathrm{d}$ & $\mathrm{d}$ & $\mathrm{D}$ & $\mathrm{D}$ \\
Column supplier & $\mathrm{E}$ & $\mathrm{e}$ & $\mathrm{E}$ & $\mathrm{e}$ & $\mathrm{e}$ & $\mathrm{E}$ & $\mathrm{e}$ & $\mathrm{E}$ \\
Methanol supplier & $\mathrm{F}$ & $\mathrm{f}$ & $\mathrm{f}$ & $\mathrm{F}$ & $\mathrm{F}$ & $\mathrm{f}$ & $\mathrm{f}$ & $\mathrm{F}$ \\
Chromatograph model & $\mathrm{G}$ & $\mathrm{g}$ & $\mathrm{g}$ & $\mathrm{G}$ & $\mathrm{g}$ & $\mathrm{G}$ & $\mathrm{G}$ & $\mathrm{g}$ \\
Result & $\mathrm{s}$ & $\boldsymbol{t}$ & $\boldsymbol{u}$ & $\boldsymbol{v}$ & $\boldsymbol{w}$ & $\boldsymbol{x}$ & $\boldsymbol{y}$ & $\boldsymbol{z}$ \\
\hline
\end{tabular}


$(\mathrm{T})$, theoretical plates number $(\mathrm{N})$ and lumefantrine content were evaluated. By means of Youden's test, it is possible to establish certainly the parameters which present higher influence in the final result of the analyses and perform a more rigorous control in the eventual variations of these parameters that may occur during a routine analysis.

\section{RESULTS AND DISCUSSION}

The assays for the robustness evaluation of the chromatographic method were carried out simultaneously in both equipments, Agilent 1200 e HP1100. A Symmetry column was initially tested in Agilent 1200 chromatograph, while the analyses were performed with Ace column at HP1100 chromatograph. Afterward, the columns were changed in the equipments.

The results obtained in the eight runs to the lumefantrine sample and standard solutions are demonstrated in Table III. The values presented in the table represent the average of three injections of each solution.

To evaluate the effect of each parameter, the average of the four values corresponding to altered conditions was subtracted from the average of the four values obtained at the nominal conditions, as demonstrated in Eq. (1). The effects of the parameter variations in the analysis results are presented in Table IV.

Using the criteria of Youden's test, the chromatographic method showed to be highly robust regarding the

TABLE III - Results obtained in eight runs performed for robustness evaluation, for lumefantrine sample (Sam.) and standard (Stan.) solutions

\begin{tabular}{lccccccccc}
\hline Condition & \multicolumn{3}{c}{ Area } & \multicolumn{2}{c}{ Retention time } & \multicolumn{2}{c}{ Tailing factor } & \multicolumn{3}{c}{ Content (\%) } \\
\cline { 2 - 10 } & Sam. & Stan. & Sam. & Stan. & Sam. & Stan. & Sam. & Stan. & \\
\hline 1 & 858 & 839 & 4.91 & 4.40 & 1.06 & 0.94 & 4730 & 4433 & 99.63 \\
2 & 876 & 855 & 6.71 & 6.67 & 1.95 & 1.92 & 5254 & 5276 & 99.80 \\
3 & 727 & 709 & 3.89 & 3.89 & 1.04 & 1.04 & 3924 & 3927 & 99.85 \\
4 & 719 & 703 & 5.63 & 5.61 & 2.57 & 2.56 & 3433 & 3418 & 99.63 \\
5 & 726 & 711 & 10.26 & 10.25 & 1.92 & 1.90 & 5350 & 5456 & 99.48 \\
6 & 710 & 694 & 5.66 & 5.60 & 1.09 & 1.09 & 4509 & 4403 & 99.64 \\
7 & 857 & 838 & 12.27 & 11.75 & 2.54 & 3.00 & 5056 & 3598 & 99.60 \\
8 & 870 & 852 & 4.55 & 4.40 & 1.05 & 1.02 & 5020 & 4467 & 99.51 \\
\hline
\end{tabular}

TABLE IV - Effects of the analytical parameters in content, retention time (Rt), tailing factor (T) and theoretical plates number (N) of the chromatographic method for lumefantrine quantitation

\begin{tabular}{lcccc}
\hline Effect & Content $(\%)^{*}$ & Rt $(\mathrm{min})^{*}$ & Tailing factor* & $\mathrm{N}^{*}$ \\
\hline $\begin{array}{l}\text { Methanol concentration } \\
(\mathrm{A}=80 \% ; \mathrm{a}=77 \%)\end{array}$ & $99.73-99.56=\mathbf{0 . 1 7}$ & $5.14-8.00=\mathbf{- 2 . 8 6}$ & $1.62-1.75=\mathbf{- 0 . 1 4}$ & $4263-4481=\mathbf{- 2 1 8}$ \\
$\begin{array}{l}\text { Mobile phase } \mathrm{pH} \\
(\mathrm{B}=2.8 ; \mathrm{b}=3.1)\end{array}$ & $99.64-99.65=\mathbf{- 0 . 0 1}$ & $6.73-6.41=\mathbf{0 . 3 2}$ & $1.46-1.90=\mathbf{- 0 . 4 4}$ & $4892-3853=\mathbf{1 0 3 9}$ \\
$\begin{array}{l}\text { Column temperature } \\
\left(\mathrm{C}=30^{\circ} \mathrm{C} ; \mathrm{c}=35^{\circ} \mathrm{C}\right)\end{array}$ & $99.64-99.65=\mathbf{- 0 . 0 1}$ & $7.57-5.57=\mathbf{2 . 0 0}$ & $1.72-1.65=\mathbf{0 . 0 7}$ & $4353-4391=\mathbf{- 3 8}$ \\
$\begin{array}{l}\text { Mobile phase flow rate } \\
(\mathrm{D}=1.0 \mathrm{ml} / \mathrm{min} ; \mathrm{d}=1.2 \mathrm{ml} / \mathrm{min})\end{array}$ & $99.64-99.65=\mathbf{- 0 . 0 1}$ & $6.81-6.34=\mathbf{0 . 4 7}$ & $1.72-1.65=\mathbf{0 . 0 7}$ & $4443-4301=\mathbf{1 4 2}$ \\
$\begin{array}{l}\text { Column supplier } \\
(\mathrm{E}=\text { Symmetry, }=\text { Ace })\end{array}$ & $99.66-99.63=\mathbf{0 . 0 3}$ & $4.57-8.57=\mathbf{- 4 . 0 0}$ & $1.02-2.34=\mathbf{- 1 . 3 2}$ & $4308-4437=\mathbf{- 1 2 9}$ \\
$\begin{array}{l}\text { Methanol supplier } \\
(\mathrm{F}=\text { Tedia; f }=\mathrm{J} . \mathrm{T} . \text { Baker})\end{array}$ & $99.56-99.72=\mathbf{- 0 . 1 6}$ & $6.17-6.98=\mathbf{- 0 . 8 1}$ & $1.61-1.76=\mathbf{- 0 . 1 6}$ & $4443-4301=\mathbf{1 4 2}$ \\
$\begin{array}{l}\text { Chromatograph model } \\
(\mathrm{G}=\text { Agilent } 1200 ; \mathrm{g}=\mathrm{HP} 1100)\end{array}$ & $99.63-99.66=\mathbf{- 0 . 0 3}$ & $6.84-6.30=\mathbf{0 . 5 4}$ & $1.90-1.47=\mathbf{0 . 4 3}$ & $3963-4782=\mathbf{- 8 1 9}$ \\
\hline
\end{tabular}

* Average of the values obtained at nominal conditions - average of the values obtained at altered conditions. 
lumefantrine content, when variations in seven analytical parameters were introduced. The highest variation in the lumefantrine content was $0.17 \%$, when the concentration of methanol in the mobile phase was altered; a value considerably low and not significant in routine analyses.

The retention time of lumefantrine peak was more considerably influenced by three analytical parameters. The decrease of the methanol concentration reduced the eluent strength of the mobile phase and induced the increase of the retention time of the lumefantrine peak. The change of column supplier promoted the same effect. In spite of both columns possess the same stationary phase (octadecyl silane chemically bonded to silica) and the same length $(250 \mathrm{~mm})$, changes in the supplier or even in the batch of the columns may result in significant alterations in the stationary phase selectivity. In addition, the change of the column supplier promoted also an increase of the tailing factor, due to the selectivity alteration and band broadening that is observed with the increase of retention time.

The increase of column temperature from $30^{\circ} \mathrm{C}$ to $35^{\circ} \mathrm{C}$ induced a reduction of 2 minutes in the retention time of the lumefantrine peak. In this case, a special care must be taken, since the combination of high temperatures with $\mathrm{pH}$ values close to the work limits of the column (such as $\mathrm{pH}$ 2.8) may reduce its useful life due to the silica hydrolysis in the stationary phase.

The apparent $\mathrm{pH}$ of the mobile phase presented considerable effect in the peak tailing factor. The use of a mobile phase with apparent $\mathrm{pH}$ of 2.8 assures the complete ionization of lumefantrine, which is a weak base. The increase of the mobile phase $\mathrm{pH}$ may alter the ionization, so that the analyte will be partially non ionized, resulting in peak tailing. The chromatograph model was another parameter that demonstrated influence on tailing factor. This fact may be due to a dead volume in the connections between the equipment modules.

The number of the theoretical plates is a parameter that takes into account the retention time, as well as the band broadening of the analyte peak. High retention times and low band broadening provide an elevate colu$\mathrm{mn}$ efficiency. Thus, it was possible to observe a direct correlation between the theoretical plates number and the retention time and tailing factor in the results of Table IV. The increase of the apparent $\mathrm{pH}$ of the mobile phase, for example, promoted an increase in the tailing factor and consequently a significant decrease in the theoretical plates number, indicating reduction of the column efficiency. The change of the chromatograph model presented the inverse effect, i.e., tailing factor decrease and so, increase of the- oretical plates number. The alteration of column supplier did not promote significant variations in the theoretical plates number, probably because the increase of the tailing factor was compensated by the considerable increase of the retention time.

Some parameters such as mobile phase flow rate and methanol supplier presented low influence in the evaluated factors of the chromatographic method.

\section{CONCLUSION}

Youden's test showed to be a reliable and useful tool for the robustness evaluation of the chromatographic method for lumefantrine quantitation in raw material. By means of this test, it was possible to evaluate the effect of seven analytical parameters in the final result of the analyses, performing only eight runs. Therefore, Youden's test can be successfully applied for the robustness evaluation in validation process of analytical methods by HPLC.

\section{REFERENCES}

ANNERBERG, A.; SINGTOROJ, T.; TIPMANEE, P.; WHITE, N. J.; DAY, N. P. J.; LINDEGARDH, N. High throughput assay for the determination of lumefantrine in plasma. $J$. Chromatogr. B, v.822, n.1-2, p.330-333, 2005.

BAKSHI, R.; HERMELING-FRITZ, I.; GATHMANN, I., ALTERI, E. An integrated assessment of the clinical safety of artemether-lumefantrine: a new oral fixed-dose combination antimalarial drug. Trans. R. Soc. Trop. Med. Hyg., v.94, n.4, p.419-424, 2000.

BRASIL. Ministério da Saúde. Agência Nacional de Vigilância Sanitária. Resolução RDC n 899, de 29 de maio de 2003. Guia de Validação de Métodos Analíticos e Bioanalíticos. Diário Oficial da União, Brasília, 31 mai 2003. Available at: < http://e-legis.bvs.br/leisref/public/show Act. php?id=15132\&word=>. Access on: 28 abr. 2006.

BRASIL. Ministério da saúde. Secretaria de Vigilância em Saúde. Programa Nacional de Controle da Malária. Esquemas recomendados para o tratamento da malária não complicada no Brasil. Brasília: Editora MS, 2006. p 1-4.

CÉSAR, I.C.; NOGUEIRA, F.H.A.; PIANETTI, G.A. Comparison of HPLC, UV spectrophotometry and potentiometric titration methods for the determination of lumefantrine in pharmaceutical products. J. Pharm. Biomed. Anal., v.48, n.3, p.223-226, 2008. 
DEJAEGHER, B.; HEYDEN, Y. V. Ruggedness and robustness testing. J. Chromatogr. A, v.1158, n.1-2, p.138-157, 2007.

GREEN, J. M. A practical guide to analytical method validation. Anal. Chem., v.68, n.1, p.305-309, 1996.

INMETRO - Instituto Nacional de Metrologia, Normalização e Qualidade Industrial. Orientações sobre validação de métodos de ensaios químicos - DOQ-CGCRE-008. Rio de Janeiro, março de 2003. Available at: < http://www. inmetro.gov.br/Sidoq/Arquivos /CGCRE/DOQ/DOQCGCRE-8_02.pdf> Access on: 02 jul. 2007.

INTERNATIONAL Conference on Harmonization of Technical Requirements for Registration of Pharmaceuticals for Human Use. Validation of Analytical Procedures: Methodology-Q2B. Geneva, November 1996. Available at: <http://www.ich.org >. Access on: 23 jul. 2006.

LINDEGARDH, N.; ANNERBERG, A.; BLESSBORN, D.; BERGQVIST, Y.; DAY, N.; WHITE, N. J. Development and validation of a bioanalytical method using automated solid-phase extraction and LC-UV for the simultaneous determination of lumefantrine and its desbutyl metabolite in plasma. J. Pharm. Biomed. Anal., v.37, n.5, p.1081-1088, 2005 .

MANSOR, S. M.; NAVARATNAM, V.; YAHAYA, N.; NAIR, N. K.; WERNSDORFER, W. H.; DEGEN, P. H. Determination of a new antimalarial drug, benflumetol, in blood plasma by high-performance liquid chromatography. J. Chromatogr. B, v.682, n.2, p.321-325, 1996.
MARTENSSON, A.; STROMBERG, J.; SISOWATH, C.; MSELLEM, M. I.; GIL, J. P.; MONTGOMERY, S. M.; OLLIARO, P.; ALI, A. S.; BJORKMAN, A. Efficacy of artesunate plus amodiaquine versus that of artemetherlumefantrine for the treatment of uncomplicated childhood Plasmodium falciparum malaria in Zanzibar, Tanzania. Clin. Infect. Dis., v.41, n.8, p.1079-1086, 2005.

SUTHERLAND, C. J.; ROSALYNN, O.; DUNYO, S.; JAWARA, M.; DRAKELEY, C. J.; ALEXANDER, N.; COLEMAN, R.; PINDER, M.; WALRAVEN, G.; TARGETT, G. A. T. Reduction of malaria transmission to Anopheles mosquitoes with a six-dose regimen of coartemether. Plos Med., v.2, n.4, p.338-346, 2005.

THE UNITED STATES PHARMACOPOEIA. 30. ed. Rockville: The United States Pharmacopeial Convention, 2007. 3504 p.

YOUDEN, W. J.; STEINER, E. H. Statistical manual of AOAC - Association of Official Analytical Chemistry. Washington: AOAC, 1975.88 p.

Received for publication on $08^{\text {th }}$ july 2008 Accepted for publication on $12^{\text {th }}$ september 2008 